\title{
PENGGUNAAN ADAS DAN PULE SEBAGAI PENGHILANG RASA SAKIT DALAM USADHA BALI (USADHA DALEM)
}

\author{
Warditiani, N.K. ${ }^{1}$, Leliqia, N.P.E., Dewi, N.K.I.P ${ }^{1}$, Suyadnya, I.M.K.A. ${ }^{1}$, Citradewi, N.W.W. ${ }^{1}$, Megayanti, K. ${ }^{1}$, \\ Wirayanti, R. ${ }^{1}$, Pratiwi, N.L.P.A ${ }^{1}$., Esa, I.B.D. ${ }^{1}$, Prayadnya, IG.Y. ${ }^{1}$, Murti, IK.A.Y. ${ }^{1}$ \\ ${ }^{1}$ Program Studi Farmasi, Fakultas Matematika dan Ilmu Pengetahuan Alam, Universitas Udayana, \\ Bukit Jimbaran, Badung \\ kadek.warditiani@gmail.com
}

\begin{abstract}
ABSTRAK
Usadha Bali merupakan salah satu warisan budaya bangsa yang memuat tentang pemanfaatan tanaman obat untuk mengatasi masalah kesehatan yang ada di Bali. Pengobatan dengan tanaman obat masih menjadi salah satu pilihan bagi masyarakat Bali dalam mengobati penyakit-penyakit degeneratir. Dalam kajian ini akan dilakukan penelusuran penggunaan tanaman obat dalam usada disesuaikan dengan kajian ilmiah yang mendukung terhadap pemanfaatan sesuai dengan Usadha Bali. Terdapat beberapa tanaman yang memiliki kesesuaian manfaat antara penggunaan dalam usadha bali dengan kajian ilmiah, tetapi ada juga yang tidak sesuai. Adas dan pule merupakan tanaman yang pemanfaatannya dalam usada bali (usadha dalem) dan kajian ilmiah memiliki khasiat yang sama yaitu sebagai peghilang rasa sakit. Untuk tanaman dalam Usadha Bali yang belum memiliki kajian ilmiah yang sesuai dapat dijadikan sebagai ide awal untuk dilakukan pengujian secara ilmiah.
\end{abstract}

Kata kunci: usadha bali, adas, pule, kajian ilmiah

\begin{abstract}
Usadha Bali is one of the nation's cultural heritage that contains about the use of medicinal plants to overcome health problems in Bali. Treatment with medicinal plants is still one of the options for Balinese people in treating degenerative diseases. In this study will be traced the use of medicinal plants in usada adapted to scientific studies that support the utilization in accordance with Usadha Bali. There are several plants that have a suitability between usadha bali usage with scientific studies, but some are not appropriate. Fennel and pule is a plant that utilization in usada bali (usadha dalem) and scientific studies have the same efficacy that is as a pain reliever. For plants in Usadha Bali that do not have appropriate scientific studies can be used as an initial idea to do scientific study.
\end{abstract}

Keywords: usadha bali, adas, pule, scientifict study

\section{PENDAHULUAN}

Buku Usada telah diterjemahkan kedalam bahasa Indonesia oleh Fakultas Sastra Universitas Udayana.Buku Usada yang sudah diterjemahkan kedalam bahasa Indonesia akan mempermudah masyarakat awam untuk memahami isi dari buku Usada. Di dalam buku usada memuat jenis tanaman yang berkhasiat untuk mengatasi sakit dan cara penggunaannya. Perubahan bahasa dari buku Usada ini diharapkan masyarakat Bali mampu dengan mudah memahami cara pengobatan tradisional warisan nenek moyang untuk dapat diaplikasikan dalam kehidupan sehari-hari.

Telaah Usada Bali telah dilakukan di Jurusan Farmasi Universitas Udayana yaitu untuk jenis Usada Rare, Usada Netra, Usada Dalem, Usada Rukmini Tatwa dan Usada Taru Pramana. Kajian yang dilakukan adalah jenis tanaman yang dimanfaatkan dalam Usada Bali, kandungan kimia dari tanaman tersebut dan kajian praklinik sesuai dengan manfaat dalam Usada Bali. Berikut adalah nama tanaman yang telah dikaji adalah adas, bangle, bawang putih, 
belimbing besi, delima, kelor, kemiri, kencur, ketumbar, kunir, pulasari, pule, sembung, sirih, tapak liman, sembukan, bawang putih, cabe jawa, jambu biji, dringo, jahe, jeruk nipis, nusa indah, pegagan, iler, kedongdong hutan, mengkudu, sirih, daun ungu, dadap serep, kayu putih, kemiri, ketumbar, simbukan, papaya, pala. selain penelusuran jenis tanaman, kandungan kimia dan manfaat praklinik dari tanaman yang terdapat dalam Usada Bali, telah dilakukan pula kompilasi data tersebut ke dalam electronic file (e-file). Hal ini dilakukan untuk mempermudah penelusuran data, meminimalisir kertas dan mencegah lapuknya kertas.

Perlu juga dilakukan penelusuran kesesuaian penggunaan dalam usada bali terhadap kajian ilmiah dari penggunaan tanaman obat tersebut. Pada kajian ini akan dilakukan penelusuran tanaman adas (Foeniculum vulgare Mill.) dan pule (Alstonia scholaris) terhadap kasiatnya sebagai penghilang rasa sakit. Penggunaan secara usadha bali, empiris di masyarakat dan kajian ilmiah akan dibandingkan pada tulisan ini.

\section{METODE PENELITIAN}

\subsection{Bahan dan alat}

Bahan-bahan yang digunakan adalah buku usadha bali dan jurnal-jurnal terkait. Alat yang digunakan adalah laptop dan internet.

2.2 Metode penelitian

Pada penelitian ini dilakukan penelurusuran pustaka dari lontar usadha bali, jurnal terkait dan dilengkapi dengan gambar dari tanaman tersebut.

\section{HASIL}

\subsection{Adas (Foeniculum vulgare Mill.)}

Secara tradisional dalam usadha bali, adas digunakan untuk pengobatan penyakit buh, kaki membengkak terasa sakit dan panas, dan luka akibat gigitan ular (Anonim, 2008). Adapun cara penggunaan dari adas pada usadha bali adalah sebagai berikut:

a. Penyakit buh (penyakit yang menampakkan gejala-gejala pembengkakan pada bagian rongga perut) yang tanpa diketahui sebabnya. Bahan obatnya adalah adas, bawang dan daun kecubung yang selanjutnya diproses menjadi obat oles b. Kaki membengkak terasa sakit dan panas, bahan obatnya adalah adas, bawang, daun dap-dap dan kemiri. Bahan dikunyah dan disemburkan pada bagian yang bengkak

c. Luka akibat gigitan ular, bahan obatnya adalah adas, akar paspasan dan air basuhan beras. Adas dan akar paspasan digiling, kemudian dicampur dengan air pembasuh beras dan langsung dioleskan pada luka gigitan (Anonim, 2008)

Adas memiliki nama berdasarkan lontar usadha, nama ilmiah, dan nama Indonesia. Nama Indonesia : Adas; Nama Ilmiah: Foeniculum vulgare Mill (Hutapea. 2001); Nama Usada: Adas, Puspa Tandah (Tengah, dkk., 1995). Selain itu dalam buah adas mengandung limonen, minyak lemak, stigmasterol, kamfena, limonen, arginin, umbeliferona, gula, saponin, flavonoid, polifenol, anetol, fenkon, pinen, dipenten, felandren, metilkavikol, anisaldehid dan asam anisat (Hutapea. 2001), limonen, estragol, terpinen, senyawa kumarin berupa bergapten dan xantotoksin, $\beta$-sitosterol, a-amirin, asam klorogenat, dan kuersetin-3-O-ß-glukoronida (Tengah, dkk., 1995).

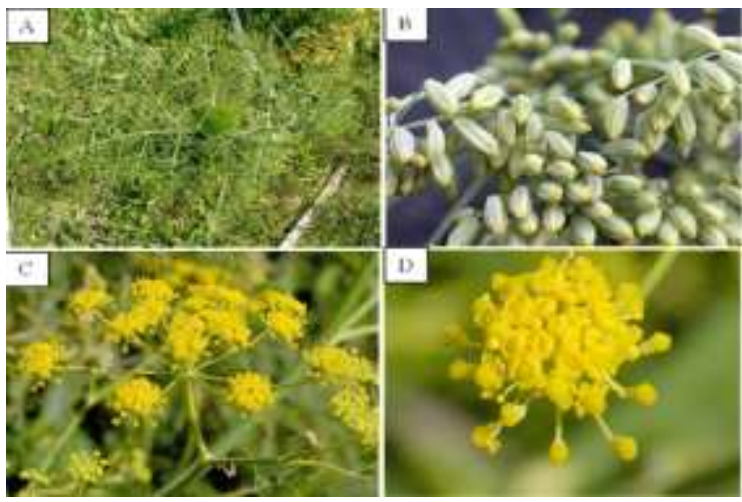

Gambar 1. Daun (A), buah adas (B), bunga adas $(\mathrm{C}, \mathrm{D})$ (Foeniculum vulgare)

\subsection{Pule (Alstonia scholaris)}

Begitu pula untuk penggunaan pule dalam usadha bali, kulit kayu pule digunakan untuk mengobati perut yang terasa kaku (keras). Adapun cara penggunaan dari adas pada usadha bali yaitu kulit pohon pule ditambahkan dengan sembung dang kayu melelo yang kemudian dicampur digiling dan diperas lalu disaring. Kemudian air hasil saringan ditambahkan dengan madu, diberikan sebagai obat minum (Anonim, 2008). Pule memiliki nama berdasarkan lontar usadha, nama ilmiah, dan nama Indonesia. Nama 
Indonesia : Pule; Nama Dagang Internasional : Ditta bark tree; Nama Usada : Pule, kayu pahit, luwed agung, kayu agung, taru agung (Tengah, dkk., 1995).

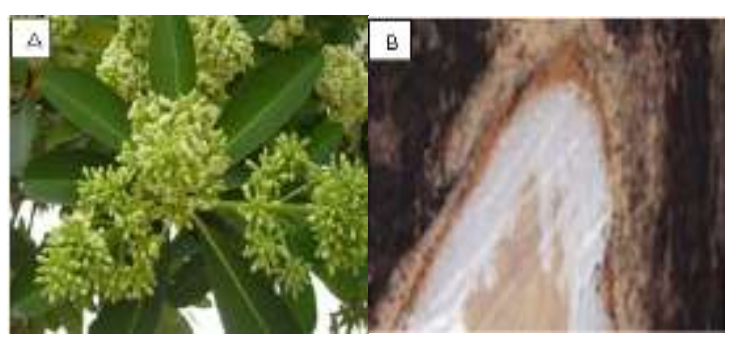

Gambar 2. Pule (Alstonia scholaris). (a) bunga dan daun pule, (b) kulit pohon pule

\section{PEMBAHASAN}

Dalam usadha bali, adas digunakan untuk pengobatan kaki membengkak terasa sakit dan panas, sedangkan pule dalam usadha bali, kulit kayu pule digunakan untuk mengobati perut yang terasa kaku. Berdasarkan hal tersebut, maka dapat dikatakan bahwa adas dan pule dapat digunakan untuk penghilang rasa sakit. Dilakukan kajian uji pustaka efek penghilang rasa sakit dari tanaman adas dan pule.

Pada penelitian yang telah dilakukan pada mencit jantan dan betina, diketahui bahwa minyak atsiri dari adas pada dosis $0,25 \mathrm{ml} / \mathrm{kg}$ bb dan $0,50 \mathrm{ml} / \mathrm{kg}$ bb memberikan efek analgesik yang sama dengan aspirin $150 \mathrm{mg} / \mathrm{kg}$ bb pada menit ke-150 setelah pemberian obat. Kandungan kimia yang diduga memiliki aktivitas sebagai analgesik adalah limonen (Ozbek, dkk., 2006). Infus 10\% kulit kayu pule pada dosis 7,5; 10; dan 12,5 g/kg berat badan, menunjukkan efek analgesik pada mencit putih dimana efektivitas akan meningkat seiring peningkatan dosis (Sulina dkk., 1978).

\section{KESIMPULAN}

Penggunaan adas dan pule dalam lontar Usadha Bali sebagai penghilang rasa sakit memiliki keselarasan dengan kajian secara ilmiah pada jurnal-jurnal ilmiah.

\section{DAFTAR PUSTAKA}

Departemen Kesehatan Provinsi Bali. 2008. Himpunan Usadha II. Denpasar: Departemen Kesehatan Provinsi Bali.

Hutapea. 2001. Inventarisasi Tanaman Obat Indonesia (I). Jilid 2. Jakarta. Balitbangkes Depkes RI.
Ismawan, Bambang. tt. Herbal Indonesia Berkhasiat. Volume 08. Jakarta. PT Trubus Swadaya.

Tengah, I Gusti Putu, I Wayan Arka, Ni Made Sritamin, I. B. Indra Gotama, dan B. Sihombing. 1995. Inventarisasi, Determinasi dan Cara penggunaan Tanaman Obat Pada Lontar Usada

Ozbek. H., A. Tas, F. Ozgokce, N. Selcuk, S. Alp and S. Karagos. 2006. Evaluation of Median Lethal Dose and Analgesic Activity of Foeniculum vulgare Miller Essential oil. International Journal of Pharmacology 2(2): 181-183

Sulina, Kosasih Padmawinata, dan Mathilda B. W. 1978. Pengujian Beberapa Efek Farmakologi Kulit Kayu Alstonia scholaris R. Br. pada Hewan Percobaan. Sekolah Farmasi ITB 